\title{
The Role of International Cooperation in Invasive Species Research
}

\author{
Andrew M. Liebhold, Faith T. Campbell, Doria R. Gordon, \\ Qinfeng Guo, Nathan Havill, Bradley Kinder, \\ Richard MacKenzie, David R. Lance, Dean E. Pearson, \\ Sharlene E. Sing, Travis Warziniack, Robert C. Venette, \\ and Denys Yemshanov
}

\subsection{Introduction}

The root cause of the biological invasion problem is globalization, which has facilitated the planet-wide breakdown of biogeographic barriers to species migration (Mooney and Hobbs 2000). In order to understand and manage the problem, coordination on a global scale is essential, and international cooperation among affected countries as well as with countries of pest origin must therefore play a critical role in virtually all aspects of research on biological invasions (Chornesky et al. 2005; McNeely et al. 2001; Perrings et al. 2010; Wingfield et al. 2015). Here we discuss key aspects of research on biological invasions, where international collaboration and coordination are important, and what infrastructures play a role in this work.

A. M. Liebhold $(\square)$

U.S. Department of Agriculture, Forest Service, Northern Research Station, Morgantown, WV, USA

e-mail: andrew.liebhold@usda.gov

F. T. Campbell

Center for Invasive Species Prevention, Springfield, VA, USA

D. R. Gordon

Environmental Defense Fund, Washington, DC, USA

Q. Guo

U.S. Department of Agriculture, Forest Service, Southern Research Station, Eastern Forest Environmental Threat Assessment Center, Research Triangle Park, NC, USA

N. Havill

U.S. Department of Agriculture, Forest Service, Northern Research Station, Hamden, CT, USA

B. Kinder

U.S. Department of Agriculture, Forest Service, Washington Office, Washington, DC, USA

R. MacKenzie

U.S. Department of Agriculture, Forest Service, Pacific Southwest

Research Station, Institute of Pacific Islands Forestry, Hilo, HI, USA
The study of invasive species in both their native and introduced ranges is critical to mitigating the invasion problem. The translocation of organisms beyond their native ranges can, in some cases, simply extend the range of species that are already pests, and in other cases it can create new pests. It is widely hypothesized that such translocations result in novel ecological interactions, which may cause these introduced (non-native) species to become more abundant and/or modify their ecosystem impacts in their new range (e.g., Broennimann et al. 2007; Torchin et al. 2003). Based on this assumption, several mechanisms have been proposed to explain why introduced species sometimes become serious pests in their new ranges (Colautti et al. 2004; Mitchell et al. 2006). Remarkably few studies have actually quantified the abundance and impact of invading species in both native and introduced ranges, to test the

D. R. Lance

U.S. Department of Agriculture, Animal and Plant

Health Inspection Service, Plant Protection and Quarantine, Center for Plant Health Science and Technology, Buzzards Bay, MA, USA

D. E. Pearson

U.S. Department of Agriculture, Forest Service, Rocky Mountain Research Station, Missoula, MT, USA

Ecology and Evolution, Division of Biological Sciences, University of Montana, Missoula, MT, USA

S. E. Sing

U.S. Department of Agriculture, Forest Service, Rocky Mountain Research Station, Bozeman, MT, USA

T. Warziniack

U.S. Department of Agriculture, Forest Service, Rocky Mountain Research Station, Fort Collins, CO, USA

R. C. Venette

U.S. Department of Agriculture, Forest Service, Northern Research Station, St. Paul, MN, USA

D. Yemshanov

Natural Resources Canada, Canadian Forest Service, Great Lakes Forestry Centre, Sault Ste. Marie, ON, Canada 
occurrence of assumed novel ecological interactions (but see Firn et al. 2011; Parker et al. 2013). Nonetheless, there are well-documented examples of non-native plants or animals that became serious pests as a result of their invasions altering hydrology, nutrient availability, fire regimes, etc. in ways that extensively change the recipient environment (see Chap. 2). Many vertebrate predator species not known to be problem species in their native ranges have become devastating pests after being introduced to island ecosystems that historically lacked predators (Blackburn et al. 2004). Extreme population growth and impacts on susceptible host trees, exhibited by many non-native herbivorous insects and tree pathogens, can be attributed in some cases to their lack of top-down control by natural enemies, or, in other systems, to a lack of coevolved resistance in host trees (Bonello et al. 2006; Colautti et al. 2004; Keane and Crawley 2002). In many cases, the transformations that create pests are much more subtle and can only be understood via international collaborations by studying the invader's population dynamics and community interactions in both its native and introduced ranges (Hierro et al. 2005).

In order to address the question of why non-native species transform into invasive pests when introduced into a new geographic range, it is critical to understand the specific changes in their ecology and community interactions that allow them to become pests. Acquiring that knowledge requires understanding how ecological interactions differ in a species' native and introduced ranges. For example, the enemy release hypothesis postulates that non-native species become problematic in their newly invaded ranges because they are released from population controls afforded by their specialist natural enemies (Keane and Crawley 2002). If this hypothesis is valid, then introducing natural enemies from the pest's native range could potentially reestablish control over its populations in the newly invaded range. This concept provides the theoretical basis for classical biological control, i.e., the introduction of natural enemies from the pest's native range to control its populations in the invaded range (van Driesche and Bellows 1996), a widely applied management tool for invasive pests which in many cases has proven to be highly successful (Huffaker and Kennett 1959; McFadyen 1998; van Driesche et al. 2008) (see Chap. 7). Similarly, when the pestilence of non-native insects or pathogens can be attributed to a lack of coevolved host tree resistance, this suggests that benefits may be gained through breeding for tree resistance (Sniezko 2006) (see Chaps. 7 and 8).

Whether translocations create new invasive pests or simply extend populations of pests, study of the invasive pest in both its native and newly invaded range can be crucial to the development of effective management strategies (e.g., McEvoy and Coombs 1999). Accordingly, for a non-native organism which becomes an invasive pest due to its translo- cation to a new range, comparing its population biology in the native and invaded ranges can identify which factor(s) drives population release in the newly invaded range, information that may be critical in formulating management strategies. For organisms that are known pest species in both ranges, studies of their populations in the native range before they are sufficiently abundant to study in the new range can be critical to containing and controlling the invader before it becomes widespread. Furthermore, when eradication is being employed, it is impractical to work with target organisms in the field in the introduced range; aside from working in a quarantine facility, the only alternative for acquiring needed research involves conducting biological studies in the native range or elsewhere within the introduced range. Consequently, international collaboration among researchers and managers across the native and introduced ranges is crucial.

All biological invasions can be partitioned into three major phases: arrival, establishment, and spread. Management strategies corresponding to each of these phases are prevention of species arrival, eradication (purposefully driving a species to extinction over a specific area) to prevent establishment, and containment to prevent or slow spread (see Chap. 6). Once non-native species become widely established and eradication is no longer possible, other management options, such as biological control or breeding resistant trees, may be appropriate (see Chaps. 7 and 8).

\subsection{Prevention}

A key step in the prevention of destructive invasions is to identify potentially damaging species in native habitats in their regions of origin and use this information to designate import quarantines. However, obtaining information about potential invaders, both in their native ranges and invaded ranges outside of the United States, may be difficult. Thus, international collaboration and data sharing are critical to implementing effective biosecurity strategies.

Available Data Information that is available through the public domain has vastly increased our ability to access and share specialized information on invasive species. The International Association for the Plant Protection Sciences disseminates largely informal reports on plant pests and their management in both their native and invaded ranges through a dedicated website, Global Plant Protection News (https:// iapps2010.me). The Centre for Agriculture and Bioscience International's (CABI) Invasive Species Compendium (https://www.cabi.org/isc) is an encyclopedic resource with detailed datasheets that have been sourced from experts and peer-reviewed literature and includes images and range maps. The North American Plant Protection Organization's 
(NAPPO) Phytosanitary Alert System (PAS) https://www. pestalerts.org) provides up-to-date information on developing plant pest problems that are just beginning or are likely to become significant in North America. The mission of the PAS is to facilitate awareness, detection, prevention, and management of new or potential exotic pest species through official pest reports and emerging pest alerts. Official pest reports are provided by the respective national plant protection organizations of Canada, the United States, and Mexico and serve as the official communication from the country of origin to comply with the International Plant Protection Convention's (IPPC) Standard on Pest Reporting (ISPM-17). Pest reports typically contain useful information on an invasive species: (1) detection or eradication in a specified location, (2) updated regulated areas, and (3) reports on new establishments or expansion of quarantine areas. Emerging pest alerts are not official NAPPO communiqués but instead are relevant (but unvetted) communications obtained from public sources that are posted on the PAS. Alerts are intended to function as an early warning tool for emerging plant pests that are not yet present in North America. The National Agricultural Pest Information System's Pest Tracker (http:// pest.ceris.purdue.edu/index.php) provides information and distribution maps for invasive species already established in the United States, organized by taxonomic category as follows: bacteria, fungi, gastropods, insects, mites, nematodes, phytoplasma, plants, viruses, and others. This resource could be useful for identifying invasions occurring in new areas of the United States or forecasting potential local invasion sites based on their proximity to established populations and habitat similarities.

The US Department of Agriculture Animal and Plant Health Inspection Service (USDA APHIS) has regulatory responsibility for protecting U.S. agricultural and natural resource interests. The plant health branch of the APHIS, Plant Protection and Quarantine (PPQ), has a mandate to safeguard U.S. agriculture and natural resources against the entry, establishment, and spread of economically and environmentally significant pests and to facilitate the safe trade of agricultural products. The Center for Plant Health Science and Technology (CPHST) depends on international data and collaborations to provide information, tools, and technology for scientific support of PPQ's regulatory decisions and operations. Within the CPHST, the Plant Epidemiology and Risk Analysis Laboratory (PERAL) assesses pest risks incurred through the import and export of plant products. PERAL participates in a range of risk assessment activities under the auspices of various working groups and units. The New Pest Advisory Group (NPAG) assesses non-native plant pests that are new or not yet present in the United States but may pose a risk to US agriculture or the environment. The Exotic Pest Information Collection and Analysis
(EPICA) project provides early warning of emerging nonnative plant pest threats before they reach the United States, through weekly e-mailed reports based on open-source plant health information analyzed and communicated within a PPQ-relevant context. The Global Pest and Disease Database is a secure database of scientific information about potentially invasive pests of concern to U.S. agriculture and is maintained and operated by the National Science Foundation's Center for Integrated Pest Management, with oversight and input on the content and direction of the database provided by the CPHST. The predictive weed screening model has been developed by PERAL to identify plants that are likely to become weedy or invasive in the United States, based on species biological traits; impacts to agricultural, natural, and anthropogenic systems; and history of invasiveness elsewhere in the world (see Chap. 6).

Risk Assessment For prevention purposes, international data collection and collaboration are particularly critical to understand whether species have become invasive anywhere outside their native range. This single variable, whether or not a species is already reported as invasive elsewhere, is among the most consistent predictors of the risk of species establishment in a new location (e.g., Bomford et al. 2009; Panetta 1993; Samways 1999). However, the surge in international trade means that increasing numbers of species with no history of prior translocation will also be introduced (Perrings et al. 2010). Risk assessment methods will, therefore, be increasingly important (see Chap. 6).

The International Pest Risk Research Group (IPRRG) is a science network that enables sharing of data and expertise for prevention of invasive species. The IPRRG is an interdisciplinary group with a diverse international composition that facilitates collaborative research and information sharing to improve plant pest risk modeling and mapping methods. Pest risk in this context refers to the likelihood that an alien species will invade and cause harm within an endangered area. Pest risk models and maps are powerful tools to support decision-making in international trade, domestic quarantines, biosecurity surveillance, or pest-incursion responses. Research in this area helps provide a thorough description of the potential harmful impacts of invasive pests across space and time and ultimately to provide a more rigorous estimation of risk and more useful information for decision-makers. This research is inherently multidisciplinary, so the IPRRG includes more than 100 ecologists, economists, modelers, and practicing risk analysts from around the world. The group also works to communicate the research findings of its members to policymakers and other biosecurity, production, and natural resource sector stakeholders through peerreviewed publications, technical presentations, and training sessions. 
Research on plant pests is a dynamic field that has been rapidly advancing in the last two decades. With many new concepts and advanced methodologies being developed, it becomes increasingly difficult for practitioners and policymakers to identify and use the most appropriate risk assessment methods for a particular pest organism. Research produced by IPRRG members has helped identify the most important activities and risk assessment methodologies to prevent the introduction of invasive alien plant pests (Venette et al. 2010). The IPRRG considers some of the most pressing research needs, ensuring inclusion of better measures and representations of uncertainty, reliable metrics of impact, incorporation of climate change (into pest risk forecasts), and clarification of how human activities might affect the course of invasions. Initial solutions to some of these needs were addressed by the group in a special issue of the international journal NeoBiota (Kriticos and Venette 2013) and a textbook (Venette 2015).

In contrast with species-specific risk assessment for plant pests, a more generalized weed risk assessment system has now been tested in many regions and countries, with productive data sharing (Chap. 6). The tool, first developed in Australia (Pheloung et al. 1999), has demonstrated similar accuracy in tropical and temperate climates and island and continental geographies (Gordon et al. 2008) and forms the basis of the weed risk assessment system developed by the USDA APHIS PPQ (Koop et al. 2012). Additional research has demonstrated that weed risk assessment systems developed for one geographical area are relevant in new locations with similar climates (Chong et al. 2011). This result illustrates the benefits of online archiving of weed risk assessment datasheets (Chap. 6). An international collaboration has also developed specific guidance for use of weed risk assessments to increase consistency and utility of these tools (Gordon et al. 2010).

Another risk assessment approach for identifying species abroad that hold potential to damage forest trees in the United States or elsewhere is the use of sentinel plantings (Britton et al. 2010; Roques et al. 2015). Under this concept, either new plantings of non-native plants or existing plantings in arboreta are monitored for damage by insects or diseases in overseas locations. Such monitoring in foreign locations serves to identify potentially invasive insects and diseases capable of severely damaging native tree species should they be introduced. This information then can be used to inform the implementation of quarantines and other practices designed to prevent these pest species from establishing in the native range of the sentinel species. This is based upon the tendency of many of the worst invasive pests to cause extensive damage because native tree species lack resistance to introduced insects and diseases with which they have no prior evolutionary exposure (Ploetz et al. 2013). The International Plant Sentinel Network (http://www.plantsenti- nel.org) was established to provide an early warning system for new and emerging pest and pathogen risks monitored via sentinel plants. Scientific evidence of known quarantine organisms and potential new risks collected from member gardens (e.g., botanical gardens, arboreta) helps NPPOs prioritize plant health activities, thereby safeguarding susceptible plant species worldwide.

Quarantine The World Trade Organization's Agreement on the Application of Sanitary and Phytosanitary Standards (SPS) identifies the IPPC as the international body responsible for setting standards for phytosanitary treatments and other plant quarantine activities (MacLeod et al. 2010). At the heart of these standards is the premise that all phytosanitary rules imposed by countries must be scientifically based. The quest for scientifically based quarantine practices thus provides challenges for researchers to develop methods for both identifying and mitigating risks.

The International Forestry Quarantine Research Group (IFQRG) is a scientific advisory body composed of scientists from around the world (including the USDA Forest Service) that provides the IPPC with key information for setting policy and identifying research priorities on quarantine and other prevention activities. Over the last two decades, Forest Service scientists working in support of the IFQRG have played key roles in developing ISPM-15, an international standard for phytosanitary measures ratified by the IPPC that specifies mandatory treatment of solid wood packing material used to ship products between countries. Its main purpose is to provide a mandatory, harmonized phytosanitary treatment to prevent the international transport and spread of plant diseases and pest insects. Forest Service scientists played a key role in the original specification of the ISPM-15 treatment and in evaluation of its operational impact (Brockerhoff et al. 2014; Haack and Petrice 2009; Haack et al. 2014).

Additional Prevention Approaches Another area where international scientific collaboration plays a key role in preventing the introduction of invasive species is through identifying invasion pathways. By analyzing patterns of historical establishments around the world and categorization of organisms intercepted by port inspectors, scientists have made progress in identifying important pathways for insect, disease, vertebrate, and plant invasions, which include solid packing material, imported live plants, air passengers, and containerized cargo (Brockerhoff et al. 2016; Liebhold et al. 2006, 2012, 2016a; Smith et al. 2009). Identification of invasion pathways provides critical information necessary for implementing phytosanitary measures. Pathway identification has also made it possible to identify when and where to strategically apply prophylactic treatments such as 
fumigation, insecticide applications, disinfection, cold, heat, and irradiation or physical pest removal offshore, as part of a systems approach to phytosanitation (Hennessey et al. 2014).

The implementation of quarantine practices outside of North America can be highly effective in preventing the establishment of new invasions in the United States. One reason for this is the "bridgehead effect," in which a species may initially invade one part of the world where it becomes abundant and thus a source for accidental transport elsewhere (Garnas et al. 2016). Implementing globally harmonized quarantine measures is ultimately a more effective approach to mitigating economic impacts than implementing activities made after a pest is detected in the United States (Perrings et al. 2010). Realizing this approach, however, may necessitate investing in capacity building of quarantine and research programs in other countries, particularly those with developing economies. The Food and Agriculture Organization (FAO) of the United Nations conducts extensive capacity building through their Regional Forest Invasive Species Networks (http://www.fao.org/forestry/pests/en).

The USDA APHIS' International Technical and Regulatory Capacity Building Center specializes in program coordination, including technical and regulatory capacity building efforts with US and foreign government counterparts. The Center focuses on training and technology transfer needed to support sanitary and phytosanitary (SPS) issues related to safeguarding of US agriculture from foreign plant pests and animal diseases as well as expanding US international trade.

The USDA Foreign Agricultural Service also supports international SPS capacity building. Scientists in the United States are invested in overseas research capacity building in the fields of taxonomy and species identification, surveillance, and phytosanitary practices that will facilitate pestfree imports to the United States. These ongoing efforts to share scientific expertise abroad ultimately benefit the United States by reducing the probability that invasive species enter invasion pathways.

International education on the nature of invasive species and their impacts is an important measure to limit the global spread of species. This is especially true for plant, vertebrate, and aquatic species which often are intentionally introduced. Many purposeful introductions are initiated with good intentions, often by educated but ill-informed professionals who are not fully aware of the potential repercussions of introducing species to a new habitat. For example, many international nongovernmental organizations (NGOs), in their quest to seek alternative food resources for developing countries, stock aquaculture ponds with non-native tilapia or other fish. Once these fish escape, they invade adjacent aquatic habitats and often have deleterious impacts on native fish and invertebrates (e.g., Peterson et al. 2005). More recently, NGOs and countries have attempted to combat mosquito-borne diseases (e.g., Zika virus, dengue fever) by introducing non-native predators such as mosquito fish (Gambusia affinis) or guppies (Poecilia reticulata) (Azevedo-Santos et al. 2016). Some of these introductions may have resulted in negative impacts to native aquatic habitats, and yet their effectiveness has often never been determined.

A key area of research that requires international cooperation is genetic characterization of pest species across their invaded and native ranges. Such analyses can provide critical information about the chronology and source of historical invasions (e.g., for plant pests: Boissin et al. 2012; Dutech et al. 2012; Havill et al. 2016; for invasive plants: Gaskin et al. 2013; Tarin et al. 2013; Williams et al. 2005). Since it is usually not clear exactly where an introduced pest originated, genetic analysis can often pinpoint the source locality and better determine the pathway of introduction. This information is particularly useful when conducting foreign exploration for new biological control agents and for identifying natural enemies that are well adapted to the specific strain of pest that was introduced. Genetic characterization can also provide critical information for identifying cryptic strains, siblings, or hybrids of species (e.g., Gwiazdowski et al. 2011; Toševski et al. 2011; Ward et al. 2009). For example, hemlock woolly adelgid (Adelges tsugae), an introduced insect pest of hemlock (Tsuga spp.) trees in the Eastern United States, was known to occur throughout East Asia and Western North America; however, the source of the introduction was unknown. Genetic studies showed that there are up to eight genetically divergent groups in Asia, that the source of the introduction to the Eastern United States was Southern Japan, and that the strain in Western North America is native to that region and probably arrived there just prior to the last glacial period (Havill et al. 2016). Consequently, the search for the most effective natural enemies of hemlock woolly adelgid is now focused in Japan and Western North America (Havill et al. 2014). Completing studies of this nature requires international collaborations between scientists in the invaded countries and scientists in source countries, who can provide critical local taxonomic expertise and logistical support for collecting samples.

\subsection{Surveillance/Eradication}

Surveillance for populations of newly arrived non-native species is crucial to their early detection, and eradication is most likely to be successful when target populations are still small (Liebhold et al. 2016b; Rejmánek and Pitcairn 2002) (see Chap. 6).

Most surveillance programs for non-native insects utilize attractant traps baited with pheromones or host attractants. In order to develop such lures, it is often necessary to conduct field tests abroad in the species' native range. For example, 
studies of pheromone communication used in surveillance trapping can most effectively be carried out in world regions where these species are already established. International collaboration is thus key to developing effective surveillance programs. There are numerous examples of Forest Service scientists collaborating with overseas scientists to test semiochemical attractants abroad (e.g., Fan et al. 2010; Meng et al. 2014). One of the challenges arising in programs to eradicate newly discovered insect populations is the lack of information on efficacious treatment methods. Frequently, little information is available on how to control these species even in their native ranges. Consequently, it may be necessary to evaluate treatment methods in the organism's native range. For example, Forest Service scientists collaborated with APHIS PPQ staff and Chinese scientists to test the efficacy of different insecticide treatments for Asian long-horned beetle (Anoplophora glabripennis) populations in China so that these methods could be applied for eradication of incipient Asian long-horned beetle populations in the United States (Poland et al. 2006; Wang et al. 2003) (Fig. 13.1).

In recent years, there has been considerable progress in understanding the population biology of invading organisms and applying that knowledge to develop more effective strategies for eradicating invasive populations. As in other settings, sharing of experiences and knowledge about eradication efforts among countries can provide valuable information. One example of this approach was formation of a working group at the National Center for Ecological Analysis and Synthesis (University of California, Santa Barbara) entitled "Applying population ecology to strategies for eradicating invasive forest insects." This group consisted of an international team of scientists that investigated more effective strategies for detecting and eradicating invading

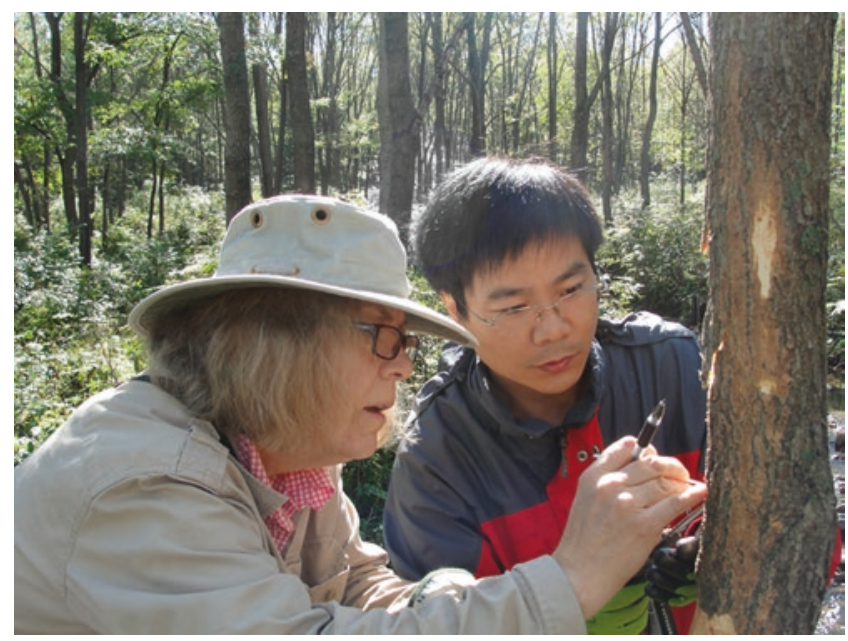

Fig. 13.1 Dr. Leah Bauer (USDA Forest Service) (left) and Xiaoyi Wang (Chinese Academy of Forestry) examining parasitized emerald ash borer larvae in ash trees in Liaoning Province, China, 2013 (Photo by Jian Duan, ARS) forest insect populations (Liebhold et al. 2016b). One product of this work was the assembly and analysis of a global database of insect eradication programs that yielded new insight into the determinants of successful eradication programs (Kean et al. 2016; Tobin et al. 2014).

Once non-native species become established, they enter the spread phase, during which they expand their range into previously unoccupied habitats. Predictions of future spread are valuable to many different activities, including forest management, where knowledge of when an invading species is likely to invade new regions may be crucial. An example of how international collaboration has provided critical knowledge about spread is provided by the Sirex woodwasp (Sirex noctilio). This species, native to Europe, invaded most pine-growing regions of the Southern Hemisphere several decades ago but only recently became established in the Northeastern United States. An international team of insect ecologists assembled and analyzed data on the historical spread of this insect in various regions of the Southern Hemisphere and used this valuable information to predict the future spread of Sirex woodwasp in North America (Lantschner et al. 2013).

In the cases of plant invasions, international collaboration is needed particularly with reciprocally exchanged species. Plant ecologists in Eastern Asia, Europe, and North America are focusing on exchanges of species among the three continents as a direct result of rapidly growing travel and trade, the implications of these exchanges in facilitating the introduction and spread of invasive species, and the environmental and economic impacts associated with these invasions. Because Eastern Asia and North America share a wide range of similar environments, species native to one region increasingly find suitable habitat for establishment in the other (Heberling et al. 2017). Some species have become invasive, disrupting ecosystems and food webs, threatening native species, causing economic losses, and occasionally jeopardizing the health of wildlife, domestic animals, and human populations (e.g., Gordon 1998).

\subsection{Mitigation}

Biological control is an important component of invasive species research programs. A key aspect of biological control research is the search for natural enemies of invasive pests in their native range followed by intensive studies and analysis of their population ecology and host specificity, to ascertain their potential utility in the safe regulation of targeted pests and mitigation of their impacts at the population level.

The emerald ash borer (EAB) (Agrilus planipennis) biological control effort is an excellent example of a successful overseas exploration for natural enemies of an invasive pest. 
A team comprised of USDA Forest Service, Agricultural Research Service (ARS), and APHIS scientists worked with collaborators in China and Russia (Fig. 13.2) to search out populations of EAB in its native range from which parasitoids were reared and eventually shipped to quarantine facilities in the United States. There, the team performed host specificity experiments and ultimately released one egg and four larval parasitoids which have established in parts of the EAB's range (Bauer et al. 2015; Duan et al. 2012, 2015a; Liu et al. 2003). While these introductions are not anticipated to stop the current EAB outbreak that is sweeping across the Eastern and Central United States, there is a good chance that these agents will eventually contribute to the regulation of post-epidemic populations at levels low enough to allow a population of host ash (Fraxinus spp.) trees to persist and reproduce (Duan et al. 2015b).

Classical biological control of invasive toadflaxes (Linaria spp.) has relied on collaboration among US (Forest Service, Colorado and Montana State Universities), Canadian (Agriculture and Agri-Food Canada), Swiss, and Serbian (CABI) researchers. Initial reports based on greenhouse- and garden-based host specificity tests conducted overseas indicated that most biocontrol agents were equally effective against yellow toadflax (L. vulgaris) and Dalmatian toadflax (L. dalmatica). These proved to be inaccurate under North American field conditions. Subsequent molecular diagnostics revealed that releases (and redistributions) of the toadflax stem mining weevil (Mecinus janthinus) (Coleoptera: Curculionidae) included a cryptic sister species (M. janthiniformis) and that the two weevil species were highly host specific (Toševski et al. 2011). Climate matching challenges and the confirmed hybridization of yellow and Dalmatian toadflax (Ward et al. 2009) have necessitated the continuing search for candidate agents.
Several organizations provide support for biocontrol research collaboration among countries. Voluntary membership in the International Organization for Biological Control (IOBC) facilitates collaboration on a global scale among foreign and domestic scientists working toward biological control solutions. The ARS Overseas Biological Control Laboratories provide research infrastructure and networks critical for conducting foreign exploration for natural enemies and for coordinating host specificity testing. The CABI and the Biotechnology and Biological Control Agency are international nonprofit organizations that play a key role in both the development of knowledge and its application for managing invasions of both plants and plant pests.

Collaborative research on biological control must be cognizant of, and responsive to, international treaties, a challenge not incurred by many domestic research programs.

One such treaty, the Convention on Biological Diversity (CBD), is an international agreement with three main objectives: (1) the conservation of biological diversity, (2) the sustainable use of the components of biological diversity, and (3) the fair and equitable sharing of the benefits arising out of the utilization of genetic resources (https://www.cbd.int/ intro/default.shtml). The United States supports the CBD though it has never officially ratified the treaty. In 2010, the CBD Nagoya Protocol was negotiated to address the third objective. It was adopted in 2014 to recognize and protect sovereign rights over the national genetic resources of participating countries. The Nagoya Protocol broadly describes the access and benefit sharing (ABS) of national genetic resources, and practical considerations for $\mathrm{ABS}$ of specific genetic resources are stipulated in agreements established between provider and recipient nations. Development and implementation of ABS legislation and regulation is the responsibility of each participating nation, so there is a high
Fig. 13.2 Dr. Therese Poland (USDA Forest Service) (upper right) and collaborators from the Chinese Academy of Forestry and Baiyin City Forest Protection Bureau dissecting trees injected with systemic insecticides and examining Asian long-horned beetle mortality 4 months after treatment in Gansu Province, China, October 2000 (Photo by Leah Bauer, USDA Forest Service)

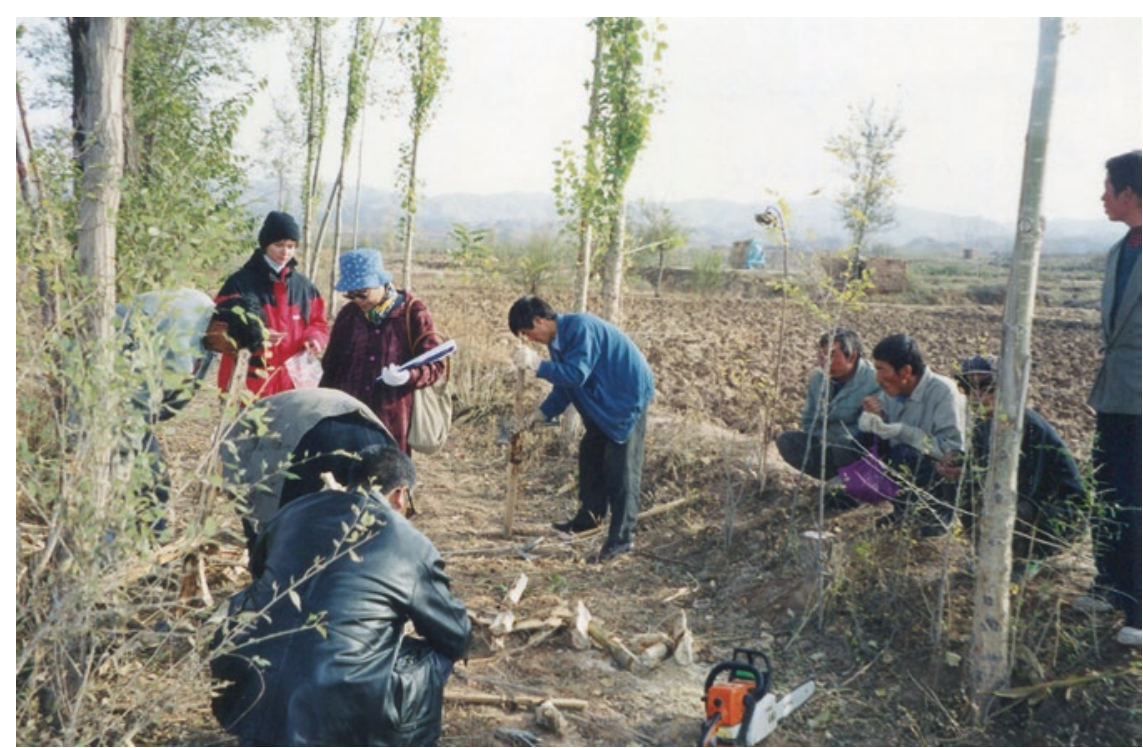


probability that interpretation of Nagoya Protocol Article 8 "Special Considerations" will vary considerably. ABS in certain cases may involve payments equivalent to royalties from the nation receiving genetic resources to the nation providing the genetic resources. The relevance of ABS to classical biological control depends on the providing nation's determination, under Article 8, that access to biological control organisms supports research benefiting agriculture and food security and as such should be subject to less complicated and costly ABS conditions due to its noncommercial nature (Gourlay et al. 2013; van Lenteren et al. 2011). Guidance on this issue was provided to the FAO in a report prepared by the IOBC (Cock et al. 2009).

Planting genetically resistant tree varieties is another method forest managers may adopt for the long-term management of invasive insect and pathogen species (Sniezko 2006). For example, one approach to developing American chestnuts (Castanea dentata) resistant to the chestnut blight fungus (Cryphonectria parasitica) involves hybridization of American chestnut with Chinese chestnut (C. mollissima) and repeated backcrossing to American chestnut (Diskin et al. 2006). A key component of such resistance development programs is having access to a wide global selection of plant germplasm. International collaboration thus may play an important role in facilitating such resistance programs.

\subsection{Overarching Efforts}

In the United States, the Forest Service International Programs (IP) plays a key role in facilitating international cooperation in research on biological invasions. Their work involves providing logistical assistance to Forest Service scientists working abroad as well as to foreign scientists visiting the United States. The IP also supports technical cooperation projects that fund key aspects of invasion research as well as overseas capacity building. Furthermore, the IP engages in building partnerships with foreign governments and research organizations to help facilitate international research.

The Forest Service has established several bilateral agreements with other countries with objectives that include invasion and biosecurity research issues. One example of this is the United States-New Zealand Joint Commission on Science and Technology Cooperation which promotes collaborative research between the two countries on several topics including forest biosecurity.

In North America, cross-border collaboration among the United States, Canada, and Mexico promotes research on topics such as the analysis of spread and prediction of impacts. Invasions do not stop at borders, so the sharing of data and analyses across borders is invaluable. Information on cross-border movement of invasive organisms also helps better coordinate national surveillance and control programs and ultimately improves the efficacy of regulatory and containment measures directed against high-impact species.

Several organizations coordinate sharing of data and research on invasive species among the United States, Canada, Mexico, and, in some cases, Caribbean nations. These include consortia of the NGOs, including the North American Invasive Species Network and Weeds Across Borders. Other organizations are made up of government agencies, including the US Aquatic Nuisance Species Task Force (its Western and Northeast Regional Panels work with Canada); the North American Forest Commission Insects, Diseases, and Invasive Plants Working Group; and the binational Great Lakes Water Quality Agreement, which works to assess and improve technologies for control, eradication, and detection of invasive aquatic species and to assess these species' ecosystem impacts. The Cooperative Program in Research and Technology for the Northern Region (known as PROCINORTE) is a network of national agricultural research bodies in Mexico, the United States, and Canada. This network supports agricultural trade through sound science and knowledge sharing on issues of regional relevance.

As is the case with most scientific work, research on biological invasions is often constrained by the availability of data. In particular, there is a strong need for sharing of data on invasive species among scientists in different parts of the world. The availability of such international databases can greatly facilitate work on risk analysis, control, and other aspects of invasive species management. Several efforts have been made to develop global and regional databases on invasive species. These include the Global Invasive Species Information Network (Simpson 2004; Simpson et al. 2006) and the International Union for Conservation of Nature Invasive Species Specialist Group's (IUCN ISSG) Global Invasive Species Database (Pagad et al. 2015). International efforts such as the Global Eradication and Response Database (Kean et al. 2016) and Pherobase (El-Sayed 2014) synthesize scientific information that is used as a resource in developing surveillance and eradication programs.

International scientific societies also comprise key infrastructures that facilitate international collaboration among scientists engaged in research on invasive species. One of the most active societies is the International Union of Forest Research Organizations (IUFRO), which hosts several international research working parties (WP) and a task force that focus on the biological invasion problem. These include WP 2.02.15, "Breeding and genetic resources of five-needle pines"; WP 4.04.07, "Risk analysis"; WP 5.03.06, "Wood protection for quarantine, food packaging and trade in wood"; WP 7.03.12, "Alien invasive species and international trade"; WP 7.03.13, "Biological control of forest insects and pathogens"; WP 8.02.04, "Ecology of alien invasives"; and the 
Task Force on Biological Invasions in Forests. The IUFRO is the preeminent international body for scientific networking on forest research and, as such, plays a crucial role in the exchange of information among scientists. The IUFRO also hosts the FORENT and FORPATH Internet listservs which facilitate communication among forest entomologists and forest pathologists, respectively, on a variety of topics.

Other organizations and working groups such as the Organisation for Economic Co-operation and Development Co-operative Research Programme and the IUCN ISSG operate programs that facilitate the synthesis of scientific knowledge for use by policymakers and stakeholders. The ISSG hosts the Aliens-L Internet listserv that facilitates communication among scientists studying biological invasions as well as with policymakers and managers.

\subsection{Key Findings}

- International collaboration plays a key role in research on prevention of future invasions. Understanding species in their native ranges and how they enter invasion pathways is critical to the analysis of risk, used to guide quarantine measures.

- Scientific research conducted overseas is essential for the development of more effective surveillance and eradication methods. Testing of survey tools and treatments is often only practically conducted in foreign regions.

- History of invasions elsewhere and risk assessments conducted overseas can inform assessment of the probability of invasion in the United States, potentially enhancing prevention and eradication efforts.

- The implementation of classical biological control, and sometimes breeding of genetic resistance, requires studying the invasive species overseas and is dependent on effective coordination with foreign scientists.

- A variety of international organizations facilitate collaborative research and the exchange of data.

- International collaboration includes coordination of research among North American countries as well as among different continents and sharing of data across borders.

Disclaimer Text The findings and conclusions in this publication are those of the authors and should not be construed to represent any official USDA or U.S. Government determination or policy.

\section{Literature Cited}

Azevedo-Santos VM, Vitule JR, Pelicice FM et al (2016) Nonnative fish to control Aedes mosquitoes: a controversial, harmful tool. Bioscience 67:84-90
Bauer LS, Duan JJ, Gould JR, Van Driesche RG (2015) Progress in the classical biological control of Agrilus planipennis Fairmaire (Coleoptera: Buprestidae) in North America. Can Entomol 147:300-317

Blackburn TM, Cassey P, Duncan RP et al (2004) Avian extinction and mammalian introductions on oceanic islands. Science 305:1955-1958

Boissin E, Hurley B, Wingfield MJ et al (2012) Retracing the routes of introduction of invasive species: the case of the Sirex noctilio woodwasp. Mol Ecol 21:5728-5744

Bomford M, Kraus F, Barry SC, Lawrence E (2009) Predicting establishment success for alien reptiles and amphibians: a role for climate matching. Biol Invasions 11:713-724

Bonello P, Gordon TR, Herms DA et al (2006) Nature and ecological implications of pathogen-induced systemic resistance in conifers: a novel hypothesis. Physiol Mol Plant Pathol 68:95-104

Britton KO, White P, Kramer A, Hudler G (2010) A new approach to stopping the spread of invasive insects and pathogens: early detection and rapid response via a global network of sentinel plantings. $\mathrm{N}$ Z J For Sci 40:109-114

Brockerhoff EG, Kimberley M, Liebhold AM et al (2014) Predicting how altering propagule pressure changes establishment rates of biological invaders across species pools. Ecology 95:594-601

Brockerhoff EG, Bulman LS, Liebhold AM, Monge JJ (2016) Role of sea containers in unintentional movement of invasive contaminating pests (so-called "hitchhikers"), and opportunities for mitigation measures. Report to IPPC Commission on Phytosanitary Measures

Broennimann O, Treier UA, Müller-Schärer H et al (2007) Evidence of climatic niche shift during biological invasion. Ecol Lett 10:701-709

Chong KY, Corlett RT, Yeo DCJ, Tan HTW (2011) Towards a global database of weed risk assessments: a test of transferability for the tropics. Biol Invasions 13:1571-1577

Chornesky EA, Bartuska AM, Aplet GH, Britton KO, CummingsCarlson J, Davis FW, Eskow J, Gordon DR, Gottschalk KW, Haack RA, Hansen AJ (2005) Science priorities for reducing the threat of invasive species to sustainable forestry. Bioscience 55:335-348

Cock MJW, van Lenteren JC, Brodeur J et al (2009) The use and exchange of biological control agents for food and agriculture. FAO Background Study No. 47, FAO Rome. 88 pp

Colautti RI, Ricciardi A, Grigorovich IA, MacIsaac HJ (2004) Is invasion success explained by the enemy release hypothesis? Ecol Lett 7:721-733

Diskin M, Steiner KC, Hebard FV (2006) Recovery of American chestnut characteristics following hybridization and backcross breeding to restore blight-ravaged Castanea dentata. For Ecol Manag 223:439-447

Duan JJ, Yuchenko G, Fuester RW (2012) Occurrence of emerald ash borer (Coleoptera: Buprestidae) and biotic factors affecting its immature stages in the Russian Far East. Environ Entomol 41:245-254

Duan JJ, Gould JR, Fuester RW (2015a) Evaluation of the host specificity of Spathius galinae (Hymenoptera: Braconidae), a larval parasitoid of the emerald ash borer (Coleoptera: Buprestidae) in Northeast Asia. Biol Control 89:91-97

Duan JJ, Bauer LS, Abell KJ et al (2015b) Population dynamics of an invasive forest insect and associated natural enemies in the aftermath of invasion: implications for biological control. J Appl Ecol 52:1246-1254

Dutech C, Barres B, Bridier J et al (2012) The chestnut blight fungus world tour: successive introduction events from diverse origins in an invasive plant fungal pathogen. Mol Ecol 21:3931-3946

El-Sayed AM (2014) The Pherobase: database of pheromones and semiochemicals. http://www.pherobase.com

Fan JT, Miller DR, Zhang LW, Sun JH (2010) Effects of bark beetle pheromones on the attraction of Monochamus alternatus to pine volatiles. Insect Sci 17:553-556 
Firn J, Moore JL, MacDougall AS et al (2011) Abundance of introduced species at home predicts abundance away in herbaceous communities. Ecol Lett 14:274-281

Garnas JR, Auger-Rozenberg MA, Roques A et al (2016) Complex patterns of global spread in invasive insects: eco-evolutionary and management consequences. Biol Invasions 18:935-952

Gaskin JF, Schwarzländer M, Kinter CL et al (2013) Propagule pressure, genetic structure, and geographic origins of Chondrilla juncea (Asteraceae): an apomictic invader of three continents. Am J Bot 100:1871-1882

Gordon DR (1998) Effects of invasive, non-indigenous plant species on ecosystem processes: lessons from Florida. Ecol Appl 8:975-989

Gordon DR, Onderdonk DA, Fox AM, Stocker RK (2008) Consistent accuracy of the Australian Weed Risk Assessment system across varied geographies. Divers Distrib 14:234-242

Gordon DR, Mitterdorfer B, Pheloung PC et al (2010) Guidance for addressing the Australian Weed Risk Assessment questions. Plant Prot Q 25:56-74

Gourlay AH, Shaw R, Cock MJW (2013) Workshop report: the Nagoya protocol on access to genetic resources under the convention on biological diversity. pp 493-495 In: Wu Y, Johnson T, Sing SE, Raghu S, Wheeler G, Pratt P, Warner K, Center T, Goolsby J, Reardon R (eds) Proceedings of the XIII international symposium on biological control of weeds, September 11-16, 2011, Waikoloa, HI. FHTET-2012-07

Gwiazdowski RA, Vea IM, Andersen JC, Normark BB (2011) Discovery of cryptic species among North American pine-feeding Chionaspis scale insects (Hemiptera: Diaspididae). Biol J Linn Soc 104:47-62

Haack RA, Petrice TR (2009) Bark-and wood-borer colonization of logs and lumber after heat treatment to ISPM 15 specifications: the role of residual bark. J Econ Entomol 102:1075-1084

Haack RA, Britton KO, Brockerhoff EG et al (2014) Effectiveness of the International Phytosanitary Standard ISPM No. 15 on reducing wood borer infestation rates in wood packaging material entering the United States. PLoS One 9(5):e96611

Havill NP, Vieira LC, Salom SM (2014) Biology and Control of Hemlock Woolly Adelgid, vol FHTET-2014-05. USDA Forest Service, Forest Health Technology Enterprise Team, Morgantown

Havill NP, Shiyake S, Galloway A et al (2016) Ancient and modern colonization of North America by hemlock woolly adelgid, Adelges tsugae (Hemiptera: Adelgidae), an invasive insect from East Asia. Mol Ecol 25:2065-2080

Heberling JM, Jo I, Kozhevnikov A, Lee H, Fridley JD (2017) Biotic interchange in the Anthropocene: strong asymmetry in East Asian and eastern North American plant invasions. Glob Ecol Biogeogr 26:447-458

Hennessey MK, Jeffers L, Nendick D et al (2014) Chapter 10: Phytosanitary treatments. In: Gordh G, McKirdy S (eds) The handbook of plant biosecurity. Springer, Dordrecht, pp 269-308

Hierro JL, Maron JL, Callaway RM (2005) A biogeographical approach to plant invasions: the importance of studying exotics in their introduced and native range. $\mathrm{J}$ Ecol 93:5-15

Huffaker CB, Kennett CE (1959) A ten-year study of vegetational changes associated with biological control of Klamath weed. J Range Manag 12:69-82

Kean JM, Suckling DM, Sullivan NJ et al (2016) Global eradication and response database. http://b3.net.nz/gerda. Accessed 20 Mar 2016

Keane RM, Crawley MJ (2002) Exotic plant invasions and the enemy release hypothesis. Trends Ecol Evol 17:164-170

Koop A, Fowler L, Newton L, Caton B (2012) Development and validation of a weed screening tool for the United States. Biol Invasions 14:273-294

Kriticos DJ, Venette RC (eds) (2013) Advancing risk assessment models to address climate change, economics and uncertainty. NeoBiota $18: 1-7$
Lantschner MV, Villacide JM, Garnas JR et al (2013) Temperature explains variable spread rates of the invasive woodwasp Sirex noctilio in the Southern Hemisphere. Biol Invasions 16:29-339

Liebhold AM, Work TT, McCullough DG, Cavey JF (2006) Airline baggage as a pathway for alien insect species invading the United States. Am Entomol 52:48-54

Liebhold AM, Brockerhoff EG, Garrett LJ et al (2012) Live plant imports: the major pathway for forest insect and pathogen invasions of the US. Front Ecol Environ 10:135-143

Liebhold AM, Yamanaka T, Roques A et al (2016a) Global compositional variation among native and non-native regional insect assemblages emphasizes the importance of pathways. Biol Invasions 18:893-899

Liebhold AM, Berec L, Brockerhoff EG et al (2016b) Eradication of invading insect populations: from concepts to applications. Annu Rev Entomol 61:335-352

Liu HP, Bauer LS, Gao RT et al (2003) Exploratory survey for the emerald ash borer, Agrilus planipennis (Coleoptera: Buprestidae), and its natural enemies in China. Great Lakes Entomol 36:191-204

MacLeod A, Pautasso M, Jeger MJ, Haines-Young R (2010) Evolution of the international regulation of plant pests and challenges for future plant health. Food Secur 2:49-70

McEvoy PB, Coombs EM (1999) Biological control of plant invaders: regional patterns, field experiments, and structured population models. Ecol Appl 9:387-401

McFadyen RE (1998) Biological control of weeds. Annu Rev Entomol 43:369-393

McNeely JA, Mooney HA, Neville LE et al (2001) Global strategy on invasive alien species. Global Invasive Species Programme (GISP), Gland/Cambridge. 63 pp

Meng PS, Trotter RT, Keena MA et al (2014) Effects of pheromone and plant volatile release rates and ratios on trapping Anoplophora glabripennis (Coleoptera: Cerambycidae) in China. Environ Entomol 43:1379-1388

Mitchell CE, Agrawal AA, Bever JD et al (2006) Biotic interactions and plant invasions. Ecol Lett 9:726-740

Mooney HA, Hobbs RJ (2000) Invasive species in a changing world. Island Press, Washington, DC

Pagad S, Genovesi P, Carnevali L et al (2015) IUCN SSC Invasive Species Specialist Group: invasive alien species information management supporting practitioners, policy makers and decision takers. Manage Biol Invasions 6:127-135

Panetta FD (1993) A system for assessing proposed plant introductions for weed potential. Plant Prot Q 8:10-14

Parker JD, Torchin ME, Hufbauer RA et al (2013) Do invasive species perform better in their new ranges? Ecology 94:985-994

Perrings C, Burgiel S, Lonsdale M et al (2010) International cooperation in the solution to trade-related invasive species risks. Ann N Y Acad Sci 1195:198-212

Peterson MS, Slack WT, Woodley CM (2005) The occurrence of non-indigenous Nile tilapia, Oreochromis niloticus (Linnaeus) in coastal Mississippi, USA: ties to aquaculture and thermal effluent. Wetlands 25:112-121

Pheloung PC, Williams PA, Halloy SR (1999) A weed risk assessment model for use as a biosecurity tool evaluating plant introductions. J Environ Manag 57:239-251

Ploetz RC, Hulcr J, Wingfield MJ, De Beer ZW (2013) Destructive tree diseases associated with ambrosia and bark beetles: black swan events in tree pathology? Plant Dis 97:856-872

Poland TM, Haack RA, Petrice TR et al (2006) Field evaluations of systemic insecticides for control of Anoplophora glabripennis (Coleoptera: Cerambycidae) in China. J Econ Entomol 99:383-392

Rejmánek M, Pitcairn MJ (2002) When is eradication of exotic plants a realistic goal? In: Veitch CR, Clout MN (eds) Turning the tide: the eradication of invasive species. IUCN SSC Invasive Species Specialist Group, IUCN [World Conservation Union], Gland/ Cambridge, pp 249-253 
Roques A, Fan JT, Courtial B, Zhang YZ et al (2015) Planting sentinel European trees in eastern Asia as a novel method to identify potential insect pest invaders. PloS one 10(5):e0120864

Samways MJ (1999) Managing insect invasions by watching other countries. In: Sandlund OT, Schei PJ, Viken A (eds) Invasive species and biodiversity management. Kluwer Academic Publishers, Dordrecht, pp 295-304

Simpson A (2004) The global invasive species information network: what's in it for you? Bioscience 54:613-614

Simpson A, Sellers E, Grosse A, Xie Y (2006) Essential elements of online information networks on invasive alien species. Biol Invasions 8:1579-1587

Smith KF, Behrens M, Schloegel LM et al (2009) Reducing the risks of the wildlife trade. Science 324:594-595

Sniezko RA (2006) Resistance breeding against nonnative pathogens in forest trees-current successes in North America. Can J Plant Pathol 28(S1):S270-S279

Tarin D, Pepper AE, Goolsby JA et al (2013) Microsatellites uncover multiple introductions of clonal giant reed (Arundo donax). Invasive Plant Sci Manag 6:328-338

Tobin PC, Kean JM, Suckling DM et al (2014) Determinants of successful arthropod eradication programs. Biol Invasions 16:401-414

Torchin ME, Lafferty KD, Dobson AP et al (2003) Introduced species and their missing parasites. Nature 421:628-630

Toševski I, Caldara R, Jović J et al (2011) Morphological, molecular and biological evidence reveal two cryptic species in Mecinus janthinus Germar (Coleoptera, Curculionidae), a successful biological control agent of Dalmatian toadflax, Linaria dalmatica (Lamiales, Plantaginaceae). Syst Entomol 36:741-753

Van Driesche RG, Bellows TS Jr (eds) (1996) Biological control. Chapman \& Hall, New York
Van Driesche R, Hoddle M, Center T (2008) Control of pests and weeds by natural enemies: an Introduction to biological control. Wiley, New York

van Lenteren JC, Cock MJW, Brodeur J et al (2011) Will the Convention on Biological Diversity put an end to biological control? Revista Brasileira de Entomologia 55:1-5

Venette RC (ed) (2015) Pest risk modelling and mapping for invasive alien species. CAB International, Wallingford

Venette RC, Kriticos DJ, Magarey RD et al (2010) Pest risk maps for invasive alien species: a roadmap for improvement. Bioscience 60:349-362

Wang B, Gao R, McLane WH et al (2003) Evaluation of insecticides for controlling the Asian longhorned beetle, Anoplophora glabripennis - a synthesis presentation. In: Fosbroke SLC, Gottschalk KW (eds) Proceedings, U.S. Department of Agriculture interagency research forum on gypsy moth and other invasive species 2002; 2002 January 15-18; Annapolis, MD. Gen. Tech. Rep. NE-300. U.S. Department of Agriculture, Forest Service, Northeastern Research Station, Newtown Square, pp 97-99

Ward SM, Fleischmann CE, Turner MF, Sing SE (2009) Hybridization between invasive populations of Dalmatian toadflax (Linaria dalmatica) and yellow toadflax (Linaria vulgaris). Invasive Plant Sci Technol 2:369-378

Williams DA, Overholt WA, Cuda JP, Hughes CR (2005) Chloroplast and microsatellite DNA diversities reveal the introduction history of Brazilian peppertree (Schinus terebinthifolius) in Florida. Mol Ecol 14:3643-3656

Wingfield MJ, Brockerhoff EG, Wingfield BD, Slippers B (2015) Planted forest health: the need for a global strategy. Science 349:832-836

Open Access This chapter is licensed under the terms of the Creative Commons Attribution 4.0 International License (http://creativecommons. org/licenses/by/4.0/), which permits use, sharing, adaptation, distribution and reproduction in any medium or format, as long as you give appropriate credit to the original author(s) and the source, provide a link to the Creative Commons license and indicate if changes were made.

The images or other third party material in this chapter are included in the chapter's Creative Commons license, unless indicated otherwise in a credit line to the material. If material is not included in the chapter's Creative Commons license and your intended use is not permitted by statutory regulation or exceeds the permitted use, you will need to obtain permission directly from the copyright holder. 